\title{
Effects of Blended Fertilizer Rate and Time of Application on Growth and Yield of Sugarcane Ratoon Crop at Arjo-Sugar Factory, Western Ethiopia
}

\author{
Dereje Legesse $^{1}$, Hirpa Legesse ${ }^{2 *}$ and Negash Geleta ${ }^{2}$ \\ ${ }^{1}$ Arijo-Didesa Sugar Factory, Ethiopia Sugar Corporation, Arijo, Ethiopia \\ ${ }^{2}$ Department of Plant Science, Faculty of Agriculture, Wollega university, P.O. Box: 395, Nekemte, Ethiopia
}

\begin{abstract}
Lack of appropriate agronomic practices related to fertilizer management is a major constraint to enhancing sugarcane yield in Ethiopia. The effect of optimum rate and time of blended fertilizer application on yield and quality of ratoon commercial crop is not known at Arjo Didessa Sugar factory. Therefore, the field experiments were conducted with the objectives of assessing the effect of blended fertilizer at different rate and time of application on Ratoon sugarcane growth and yield of cane. The treatments consisted of eight levels of blended fertilizer with $\mathrm{N}(0,150,111 \mathrm{~N}, 200$ and $103 \mathrm{~N}, 250$ and $94 \mathrm{~N}, 300$ and $85 \mathrm{~N}, 350$ and $76.4 \mathrm{~N}, 400$ and $68 \mathrm{~N} \mathrm{~kg} \mathrm{ha}^{-1}$ and recommended fertilizer rate) and two times of application (one and two month after harvest). The field experiments were laid out as Randomized complete block design in a factorial arrangement and replicated three times. A sugarcane cultivar named $\mathrm{N}-14$ was used as a ratoon material. Analysis of variance of the data revealed that the blended fertilizer application rate had significant effect on ratoon weight per stalk, node number, plant height, node length and cane yield sugar yield. Blended fertilizer rate and time of application and their interaction showed only highly significant on stalk girth and stalk population and interaction was significant effect on weight per stalk and node length at the time of harvest. However, application of blended fertilizer at different time and their interaction on plant height, cane yield and node number did not showed significant effect. Blended fertilizer treatment with the rate of $250 \mathrm{~kg} \mathrm{ha}^{-1}$ blended fertilizer mixed with $94 \mathrm{~kg} \mathrm{~N} \mathrm{ha}^{-1}$ at one month after harvest resulted in higher ratoon cane weight per stalk, stalk girth, cane yield, sugar yield, node length, stalk population and node number. Therefore, highest cane yield was recorded at late application time of blended fertilizer at lower dose and higher dose of nitrogen. Therefore, treating the ratoon cane by $250 \mathrm{~kg} \mathrm{ha}^{-1} \mathrm{BLF}$ with $94 \mathrm{~kg}$ $\mathrm{N} \mathrm{ha}^{-1}$ at one month after harvest had evidently the advantage of improving ratoon cane growth and yield performance.
\end{abstract}

Copyright@2016 STAR Journal, Wollega University. All Rights Reserved.

Article Information Article History:

Received : 30-01-2016

Revised : 27-03-2016

Accepted : 29-03-2016

Keywords:

Biomass

Cane Yield

Blended Fertilizer

Time of Application

Growth

*Corresponding Author:

Hirpa Legesse

E-mail:

hirpa.leg@gmail.com

\section{INTRODUCTION}

Sugarcane (Saccharum officinarum L.) is an important industrial crop cultivated in different parts of the world because of its multiple uses: it is used around the world for forage for animal feed or as raw material for the manufacture of brown sugar, molasses, alcoholic beverages, sugar and ethanol (Legendre et al., 2001). Processing its waste also has great economic importance, especially for vinasse, which is transformed into organic fertilizer, and for bagasse, which is transformed into fuel. Commercial sugarcane cultivation for the production of table sugar in Ethiopia was started by a Dutch Sugar Company called Handles Vereeniging Amsterdam (HVA) in the early 1950s at Wonji (Ambachew, 2010).

Sugarcane is a long duration exhaustive crop (Paul et al., 2005). It has been found that 85 tons of crops remove 122.24 and $142 \mathrm{~kg} \mathrm{NPK} \mathrm{ha}{ }^{-1}$, respectively from soil (Bokhtiar et al., 2001). One of the main constraints for its good yield is its high nutritional requirements along with increased cost of fertilizers (Gholve et al., 2001). Similarly, spiraling prices coupled with short availability of fertilizers (Khandagave, 2003) and depletion of available nutrients and organic matter due to continuous cane cropping with inorganic fertilizers (Kumar and Verma, 2002; Ibrahim et al., 2008; Sarwar et al., 2008a) necessitates the integrated use of organic and mineral fertilizer resources

The available literature (Faucconnier, 1993; Sundara, 2000) indicated that sugarcane is a heavy feeder of nutrients. Hence to meet nutrient requirements of the crop and achieve higher yields, mineral fertilizers are commonly applied in sugarcane production. Nitrogen is vital for most plant metabolic processes and plays an important role in tillering and stalk elongation. In addition, $\mathrm{N}$ deficiency results in reduction of leaf area and thus, causes photosynthesis reduction which in turn leads to suppress in yield and quality (Sreewarome et al., 2007). 
Fertilizers application is more common in intensive sugarcane cultivation which requires a high amount of nitrogen due to production of a great deal of biomass (Thorburn et al., 2005). The cane length and diameter, number of tillers per plant, cane yield and sugar recovery increased with the application of $\mathrm{N}$ in the sugarcane varieties (Ashraf et al., 2008). The residues from harvesting green cane, left on the soil surface where urea was incorporated in bands, reduced nitrogen volatilization and improved crop yield (Sonia et al., 2007). Marked importance in various growth, yield and yield parameters of sugarcane (Shankaraiah et al., 2007). Besides, economy in fertilizer $\mathrm{N}$ up to $20-25 \%$ is ascribed for enhanced nitrogen use efficiency for better nitrogen upon soil inoculation.

Most research work focus on NP requirements of crops, limited information is available on various sources of fertilizers $\mathrm{K}, \mathrm{S}, \mathrm{Zn}$ and $\mathrm{B}$ and other micronutrients. Therefore, application of other sources of nutrients beyond Urea and Diammonium Phosphate (DAP), especially those containing $\mathrm{K}, \mathrm{S}, \mathrm{Zn}$ and other micronutrients could increase crop productivity (CSA, 2011). This can be achieved by application of blended fertilizers, the mechanical mixture of two or more granular fertilizer materials containing $\mathrm{N}, \mathrm{P}, \mathrm{K}$ and other essential plant nutrients such as $\mathrm{S}, \mathrm{Zn}$, and $\mathrm{B}$, recently known to Ethiopia. Application of balanced fertilizers could be the basis to produce more crop output from existing land under cultivation and nutrient needs of crops according to their physiological requirements and expected yields (Ryan, 2008).

According to Bekabil et al. (2011), the lack of appropriate fertilizer blends and lack of micronutrients in fertilizer blends are the national problem which is major constraints to crop productivity. It is imperative to increase the productivity along with desirable attributes through production management practices and application of other sources of nutrients beyond the blanket recommendation of urea and DAP, especially those that contain potassium, sulphur and other micro-nutrients (CSA, 2011).

This study intends to contribute to better understanding of the soil situation regarding soil nutrient status and uptake by plants of the study area; and help in clarifying the way forward for the Sugar factory in the area. Thus, the study will address the challenges of limited knowledge on soil fertility limitations in the study area and associated challenges for increasing crop productivity with increased current fertilizer use. In addition to the similar studies being carried out on major agricultural soils throughout the country by the Ethiopian Institute of Agricultural Research (EIAR) and Sugar corporation research directorate on sugar cane crops, this study will assist in adjusting the fertilizer recommendation package for sugar cane crop, based on information gathered from the testing of new fertilizer products. This should lead to develop estate or area specific fertilizer recommendation packages, and develop soil fertility indexes to match economic optimum, soil nutrients levels and crop needs. The use of blended fertilizers for sugarcane in general and ratoon crop in particular is not known in the study area. Therefore; this research initiated to fill the information gap on blended fertilisers use as a source of fertilizer in sugar industry in the country and Arjo-Didessa sugar factory in particular. So the experiment was conducted with the objective of evaluating different rates and time of application of $N, S, p, Z n$ and B blended fertilizers on yield and quality of Sugar cane ratoon crop at Arjo-Didessa Sugar Factory southwestern Ethiopia. Thus, the objective of this study was to determine the effect of rate and time of blended fertilizer $/ \mathrm{N}, \mathrm{P}, \mathrm{S}, \mathrm{Zn}$ and $\mathrm{B} /$ application on Sugar cane ratoon growth and biomass yield.

\section{MATERIALS AND METHODS \\ Description of the Study Area}

The experiment was conducted at Arjo-Didessa Sugar Factory located in East Wollega Zone of Oromia Regional State. Arjo-Didessa Sugar Factory is located at $9^{0} \mathrm{~N}$ latitude and $39^{\circ} \mathrm{E}$ longitudes, with an altitude of 1300 1600 masl. The area receives high rain fall from June to September with average of $1477 \mathrm{~mm}$ annually. The mean average temperature of the study area is $22^{\circ} \mathrm{C}$, the soil types of the experimental site are dominated by Vertisols and few red Latosols (ESISC, 2008).

\section{Experimental Materials}

A high yielding commercial sugarcane variety named $\mathrm{N}-14$ was used as a planting material. The variety was introduced from South Africa (SASRI, 2006). It has a prostrate habit of growth after germination and canopies quickly and eventually become erect with straight stalks. It is a high yielder in terms of cane yield and the second next to variety NCO-334 in percentage sucrose content as compared to the other varieties grown at the ArjoDidessa. The planting material was obtained from harvested field of the Estate. Area for the treatment was selected from the well performer field relatively good drained, and irrigation is available.

\section{Treatment and Experimental Design}

The treatment consists seven rates of blended fertilizer $\left(0,150,200,250,300,350\right.$ and $400 \mathrm{~kg} \mathrm{ha}^{-1)}$ and two time of application (one and two months after harvest) combined factorially and arranged in randomized complete block design and replicated three times. Urea was applied with the recommended rate for the estate after calculating the amount of nitrogen available in the blended fertilizer and $200 \mathrm{~kg}$ UREA with $250 \mathrm{~kg} \mathrm{ha}^{-1}$ DAP were used as a control.

Each experimental plot composed of 6 rows of $1.45 \mathrm{~m}$ width and $5 \mathrm{~m}$ length; i.e. the net area of the experimental field used was $1957.5 \mathrm{~m}^{2}$. The central 4 rows of each plot were used for data collection. Adjacent plots were separated by leaving $1 \mathrm{~m}$ distance between each replication is 2 furrows $(2.9 \mathrm{~m})$. The fertilize were applied manually with a deep placement methods of application at one month and two month after harvest of ratoon cane. All other cultural operation (weeding, irrigation, cultivation and etc) were done as per the estate recommendation. 
Table 1: Treatment combinations, and the respective amounts of blended and nitrogen fertilizer applied to the ratoon cane plants at different rates and times after harvested for factory crashing at Arjo-Didessa, 2015/16

\begin{tabular}{|c|c|}
\hline Treatment No. & Rate and time of Blended Fertilizer application \\
\hline T1= Control One & Okg/ha \\
\hline T2 & 150kg/ha BLF + 111kg N/ha @1M \\
\hline T3 & 200kg/ha BLF + 103kg N/ha @ 1M \\
\hline T4 & $250 \mathrm{~kg} / \mathrm{ha} \mathrm{BLF}+94 \mathrm{~kg} \mathrm{~N} / \mathrm{ha} @ 1 \mathrm{M}$ \\
\hline T5 & $300 \mathrm{~kg} / \mathrm{ha} \mathrm{BLF}+85 \mathrm{~kg} \mathrm{~N} / \mathrm{ha} @ 1 \mathrm{M}$ \\
\hline T6 & $350 \mathrm{~kg} / \mathrm{ha} \mathrm{BLF}+76.4 \mathrm{~kg} \mathrm{~N} / \mathrm{ha} @ 1 \mathrm{M}$ \\
\hline T7 & 400kg/ha BLF +68 kg N/ha @1M \\
\hline $\mathrm{T} 8=$ Control two & 200kg/ha UREA + 250 kg/ha DAP @1M \\
\hline T9 = Control One & 0kg/ha@2M \\
\hline T10 & 150kg/ha BLF + 111kg N/ha @2M \\
\hline T11 & 200kg/ha BLF + 103kg N/ha @ 2M \\
\hline T12 & $250 \mathrm{~kg} / \mathrm{ha} \mathrm{BLF}+94 \mathrm{~kg} \mathrm{~N} / \mathrm{ha} @ 2 \mathrm{M}$ \\
\hline T13 & $300 \mathrm{~kg} / \mathrm{ha} \mathrm{BLF}+85 \mathrm{~kg} \mathrm{~N} / \mathrm{ha} @ 2 \mathrm{M}$ \\
\hline T14 & 350kg/ha BLF + 76.4kg N/ha @2M \\
\hline T15 & $400 \mathrm{~kg} / \mathrm{ha} \mathrm{BLF}+68 \mathrm{~kg} \mathrm{~N} / \mathrm{ha} @ 2 \mathrm{M}$ \\
\hline T16 = Control two & 200kg/ha UREA + $250 \mathrm{~kg}$ DAP/ha @ 2M \\
\hline
\end{tabular}

\section{Data Collection and Measurements}

Agronomic Parameters

Stalk Length/height: Mean ratoon cane stalk length (from zero ground level to the top visible dewlap) was measured from 20 randomly selected representative primary stalk samples of ratoon cane per plot at harvest by using a tape meter.

Cane Stalk Diameter/Girth: Mean ratoon cane stalk diameter/girth was measured after removal of sheath from three ratoon cane stalk positions; top, middle and bottom parts by using a standard caliper meter from the above 20 randomly selected representative primary stalk samples of ratoon cane per plot at harvest.

Number of Internodes per Ratoon Cane Stalk: The number of internodes per seed cane stalk (after removal of sheath and top succulent parts) was counted from the above 20 randomly selected representative primary stalk samples of ratoon cane per plot at harvest.

Raton Cane Weight per Stalk: The weight of cane stalk was taken from 20 randomly selected primary stalk samples of cane per plot at harvest and expressed as weight per stalk.

Ratoon Cane Stalk Population: Stalk count were done at harvest for each plot and converted to per hectare.

Ratoon Cane Node Length: All stalk nodes was measured from the 20 randomly selected stalks from the middle four central rows and average length were taken.

Ratoon Cane Yield: The yield of sugarcane stalks was measured and recorded at harvest from the whole area of each plot. For collection of yield data, the cane stalks were cut at the ground level by spade. Sickle was used to remove the dried old trashes and to cut green top of the cane stalks. The weight of clean cane stalks was taken for yield data. The yield of cane was expressed in $\mathrm{tha}^{-1}$.

This was estimated by multiplying the total number of millable canes from a net plot area with average weight of a single stalk taken from 20 sample millable stalks using weighing balance.

Cane yield $(\mathrm{t} / \mathrm{ha})=$ Number of stalk/ha $\times$ Average sample stalk weight $(\mathrm{kg})$

Then the value obtained per plot was converted to hectare basis as follows:

$$
\begin{aligned}
& \text { CYH }(\mathrm{t} / \mathrm{ha})=\frac{14.5 \mathrm{~m}^{2}}{\mathrm{CYP}(\mathrm{kg})} \times 1000 \mathrm{~kg} \mathrm{t}^{-1} \\
& \text { Where } \\
& \text { CYH }=\text { Cane yield per hectare } \\
& \text { CYP = Cane yield per plot. }
\end{aligned}
$$

\section{Statistical Analysis}

Finally, the data was subjected to General Linear Models Procedure (GLM) using SAS software statistical package (SAS, 2004) following a procedure appropriate to the design of the experiment. The treatment means were separated using the least significant difference at $5 \%$ levels significance.

\section{RESULTS AND DISCUSSION}

\section{Soil Chemical Properties of Experimental Site}

Soil analysis was made for the sample collected from the research site before fertilizer application from the ratoon cane and after harvesting of the ratoon for the determination of the major soil chemical properties at Nekemte Soil Research and Laboratory center (Table 2). The soil of the study site is acidic in reaction but low in exchangeable acidity. Moreover, the total nitrogen and available phosphorus of the soil were low. Therefore, the result revealed that soil of the experimental site is deficient in plant nutrients. The $\mathrm{pH}$ of the soil is medium acidic before applying the treatments but during harvesting the $\mathrm{pH}$ slightly drops and increase the acidity of the soil hence higher exchangeable acidity (Table 2). However, the organic matter content of the soil doubled at harvesting. Both calcium and magnesium slightly deceased at harvesting of ratoon cane than before application. 
Table 2: Chemical properties of the experimental soil before fertilizer application and after harvesting the ratoon at ArjoDidessa sugar factory during 2015 cropping season

\begin{tabular}{|c|c|c|c|c|c|c|c|c|c|c|}
\hline \multirow{2}{*}{ Time of Sample } & \multicolumn{10}{|c|}{ Soil Parameters } \\
\hline & $\mathrm{pH}$ & EC & N Total & Aval. P & Ex. Acidity & Ex. Ca & Ex. Mg & CEC & Organic C & OM \\
\hline Before Application & 5.73 & 0.09 & 0.16 & 3.93 & 0.00 & 8.68 & 3.75 & 18.71 & 1.82 & 3.14 \\
\hline After harvesting & 4.99 & 0.70 & 0.32 & 12.08 & 0.24 & 6.27 & 2.24 & 15.97 & 3.75 & 6.47 \\
\hline
\end{tabular}

\section{Growth and Yield Parameters}

The analysis of variance result for different characters is presented in Table 3. The analysis of variance table for blended fertilizer rate showed a highly significance $(P<0.01)$ difference for all agronomic parameters (Table 3).

Table 3: Mean square values for the parameters recorded as affected by blended fertilizer, time of application, and interaction of blended fertilizer with time of application sugarcane grown at Arjo Dedessa in 2015 cropping season

\begin{tabular}{|c|c|c|c|c|c|}
\hline \multirow{2}{*}{ Characters } & \multicolumn{5}{|c|}{ Sources of Variation } \\
\hline & FR & $\mathrm{T}$ & FR*T & MSE & REP \\
\hline Stalk Weight & $0.12^{\star \star \star}$ & $0.03^{\mathrm{ns}}$ & $0.016^{\star}$ & 0.07 & 0.01 \\
\hline Node length & $0.41^{\star \star}$ & $1.42^{\mathrm{ns}}$ & $0.61^{*}$ & 0.42 & 0.71 \\
\hline Node number & $5.36^{*}$ & $21.33^{\mathrm{ns}}$ & $3.19^{\mathrm{ns}}$ & 1.22 & 4.33 \\
\hline Stalk diameter & $0.46^{\star \star \star}$ & $0.16^{\mathrm{ns}}$ & $0.09 * *$ & 0.11 & 0.04 \\
\hline Plant height & $7.24^{\star \star \star}$ & $1.14^{\mathrm{ns}}$ & $0.81^{\mathrm{ns}}$ & 0.72 & 1.15 \\
\hline Stalk population & $5126.65^{\star \star \star}$ & $9576.75^{\star *}$ & $3461.7^{\star \star}$ & 5.77 & 25.56 \\
\hline Cane yield & $0.09^{\star \star \star}$ & $0.02^{\mathrm{ns}}$ & $0.02^{\mathrm{ns}}$ & 0.04 & 0.08 \\
\hline
\end{tabular}

$\mathrm{FR}^{\star} \mathrm{T}=$ Interaction of fertilizer rate and time of application, MSE $=$ Mean square error and REP $=$ Replication.

\section{Effect of Treatments on Weight per Stalk}

The analysis of variance showed that the effect due to blended fertilizer rate on weight per stalk were highly significant $(P<0.001)$ and the interaction effect of BLF and time of application was significant $(P<0.05)$ on weight per stalk. However, the time of application has no significant effect on the stalk weight of ratoon cane plant (Table 3 ). The highest mean weight per stalk $1.2 \mathrm{~kg} / \mathrm{stalk}$ was recorded by treating the ratoon cane with treatment combinations of $250 \mathrm{~kg} \mathrm{ha}^{-1}$ BLF with $94 \mathrm{~kg} \mathrm{~N}^{-1}$ at one month but this was statistically the same with that treated by $200 \mathrm{~kg} \mathrm{ha}^{-1} \mathrm{BLF}$ with $103 \mathrm{~kg} \mathrm{~N} \mathrm{ha}^{-1}$ at one month (Table 4). The control treatment (no fertilizer) and the recommended urea and DAP for the area ( $200 \mathrm{~kg}$ Urea and 250 DAP per hectare) gave the lowest weight per stalk. The other treatments gave almost similar weight per stalk (Table 4).

This result obtained was in line with Agarwal et al. (2003) who reported that application of $\mathrm{Zn}$ at $17.5 \mathrm{~kg} \mathrm{ha}^{-1}$ increased the average length, girth, internode number, weight cane per stalk, number of millable canes and yield of sugarcane. Basically, cane weight is a function of stalk thickness, stalk height and stalk density (Orgeron, 2003). Furthermore, Nosheen and Ashraf (2003) observed that stalk girth plays an important and dominant role in improving cane yield per unit area, which could be due to the indirect increase in stalk weight.

Table 4: Effects of Blended fertilizer combination rate and time of application on weight and node number of sugarcane ratoon crop at Arjo-Didessa

\begin{tabular}{|c|c|c|c|c|c|}
\hline \multirow{3}{*}{ T.No } & \multirow{3}{*}{ Treatment } & \multirow{2}{*}{\multicolumn{2}{|c|}{$\begin{array}{l}\text { Weight per Stalk (kg) } \\
\text { Time of Application }\end{array}$}} & \multirow{2}{*}{\multicolumn{2}{|c|}{$\begin{array}{c}\text { Stalk Population (000/ha) } \\
\text { Time of Application }\end{array}$}} \\
\hline & & & & & \\
\hline & & One month & Two Month & One Month & Two Month \\
\hline 1 & Okg ha ${ }^{-1}$ & 0.62 & 0.65 & 298.66 & 316.66 \\
\hline 2 & $150 \mathrm{~kg} \mathrm{ha}^{-1} \mathrm{BLF}+111 \mathrm{~kg} \mathrm{~N}^{-1}$ & 0.86 & 0.83 & 335.33 & 355.00 \\
\hline 3 & $200 \mathrm{~kg} \mathrm{ha}^{-1} \mathrm{BLF}+103 \mathrm{~kg} \mathrm{~N} \mathrm{ha}^{-1}$ & 1.1 & 0.89 & 360.00 & 439.33 \\
\hline 4 & $250 \mathrm{~kg} \mathrm{ha}^{-1} \mathrm{BLF}+94 \mathrm{~kg} \mathrm{~N}^{-1}$ & 1.2 & 0.96 & 346.33 & 423.00 \\
\hline 5 & $300 \mathrm{~kg} \mathrm{ha}^{-1} \mathrm{BLF}+85 \mathrm{~kg} \mathrm{~N} \mathrm{ha}^{-1}$ & 0.89 & 0.89 & 371.00 & 378.33 \\
\hline 6 & $350 \mathrm{~kg} \mathrm{ha}^{-1} \mathrm{BLF}+76.4 \mathrm{~kg} \mathrm{~N} \mathrm{ha}^{-1}$ & 0.86 & 0.83 & 342.33 & 426.00 \\
\hline 7 & $400 \mathrm{~kg} \mathrm{ha}^{-1} \mathrm{BLF}+68 \mathrm{~kg} \mathrm{~N}^{-1}$ & 0.8 & 0.79 & 358.33 & 350.00 \\
\hline \multirow[t]{4}{*}{8} & $200 \mathrm{~kg} \mathrm{ha}^{-1}$ UREA $+250 \mathrm{~kg} \mathrm{ha}^{-1}$ DAP & 0.67 & 0.71 & 402.00 & 351.66 \\
\hline & Mean & \multicolumn{2}{|c|}{0.85} & \multicolumn{2}{|c|}{365.87} \\
\hline & CV & \multicolumn{2}{|c|}{7.71} & \multicolumn{2}{|c|}{1.57} \\
\hline & LSD & \multicolumn{2}{|c|}{0.08} & \multicolumn{2}{|c|}{6.82} \\
\hline
\end{tabular}

\section{Effect of Treatments on Stalk population}

The different rate of blended fertilizer, time of application and their interaction effect on ratoon cane was highly significant $(P<0.001)$ affect the plant stalk population (Table 3 ). The $200 \mathrm{~kg} \mathrm{ha}^{-1}$ BLF plus $103 \mathrm{~kg} \mathrm{~N}$ ha $^{-1}$ applied at 2 month gave significantly higher number of plants per hectare (439.33) while the lowest was recorded at control plot (Table 4). Highest number of stalk population was recorded at 2 month than at 1 month time of application. 
Tiller density or population and biomass production are important crop variables that are used to estimate the final cane stalk population and sucrose yields. It is the most important factor that determines the overall crop stand and ultimately affects the cane yield (Sarwar et al., 2011). Tillering also fulfils damage of the ratoon cane due to different factors before and after harvesting for factory crashing (Nadeem, 2011). Therefore, the results obtained in this experiment also showed that, the maximum number of milleable cane were recorded when $200 \mathrm{~kg} \mathrm{ha}^{-1}$ BLF plus $103 \mathrm{~kg} \mathrm{~N}^{-1}$ was applied on harvested ratoon crop at 2 months after harvesting. However, this value of tiller population was in statistical parity with the ones recorded for treatment combinations of blended fertilizer application on ratoon cane crop with rate of $250 \mathrm{~kg} \mathrm{ha}^{-1}$ BLF plus $94 \mathrm{~kg} \mathrm{~N} \mathrm{ha}^{-1}$ at 2 month ratoon cane and $350 \mathrm{~kg}$ $\mathrm{ha}^{-1}$ BLF plus $176.4 \mathrm{~kg} \mathrm{~N}^{-1}$ for ratoon after harvest (Table 4).

The fertilize treated plots was significantly higher than the untreated check plot. Consistent with this result, Reghenzani et al. (1996) reported that the timing of $\mathrm{N}$ application coinciding with conditions optimum for up take by the plant can beneficially influences $\mathrm{N}$ up take of the standing seed cane plant to store maximum food reserve for the next subsequent commercial crop performance measured in terms of stalk population. One of the main factors affecting tillering of sugar ratoon cane are inorganic fertilizer applied, even though the number of developing tillers per stool varies with variety and the growing conditions (Sundara, 2000).

\section{Effect of Treatments on Stalk Girth and Node Length}

The analysis of variance showed that both stalk girth and node length of the ratoon crop was highly significantly affected $(P<0.01)$ by the main effect of blended fertilizer rate and the interaction of blended fertilizer rate and time of application (Table 3). However, time of application did not affect the stalk girth and node length of the ratoon cane (Table 3$)$. The highest stalk diameter $(3.11 \mathrm{~cm})$ was recorded under application of $250 \mathrm{~kg} \mathrm{ha}^{-1} \mathrm{BLF}$ that contained $94 \mathrm{~kg} \mathrm{~N} \mathrm{ha}^{-1}$ at one month and the highest node length $(7.4 \mathrm{~cm})$ was attained at two month of $150 \mathrm{~kg} \mathrm{ha}^{-1}$ UREA with $250 \mathrm{~kg} \mathrm{ha}^{-1}$ DAP. The least stalk diameter was recorded at both control treatments ( $0 \mathrm{~kg} \mathrm{ha}^{-1}$ and $150 \mathrm{~kg}$ $\mathrm{ha}^{-1}$ UREA with $250 \mathrm{~kg} \mathrm{ha}^{-1}$ DAP), and the least node length was recorded at control treatment $\left(0 \mathrm{~kg} \mathrm{ha}^{-1}\right)$. However, it was statistically at equivalence for most of the blended fertilizer treatments results for both parameter stalk diameter and node length (Table 4).

Moreover, high plant population produced thinner cane stalks due to crowding effect, where as low plant population produced thicker cane stalks because of the availability of wider space. This finding is in agreement with the works of Raskar and Bhoi (2003) in which in the wider spacing's there was a higher stalk weight than in the narrower spacings. Moreover, Hunsigni (1993) and Jiang (2004) also stated that as density of planting increases stalk weight decreases.

Agarwal et al. (2003) reported that application of $\mathrm{Zn}$ at $17.5 \mathrm{~kg} \mathrm{ha}^{-1}$ increased the average length, girth, internode number, weight per cane, number of millable canes and yield of sugarcane. Shahid et al. (2011) reported that number of millable canes, cane length, cane diameter, number of internodes per cane, internodal length, trash weight, weight per stripped cane, tops weight and stripped cane yield, were all significantly affected by the application of biocane (pressmud).

Ashraf et al. (2008) observed that the cane length and diameter, number of tillers per plant, cane yield and sugar recovery increased with the application of $\mathrm{N}$ in the sugarcane varieties. Sundara (2000) also described that, nitrogen is the key nutrient element influencing sugarcane yield and quality. It is required more for vegetative growth, i.e. tillering, foliage formation, stalk formation, stalk growth (internodes formation, internodes elongation, increase in stalk girth and weight) and root growth. But the author further revealed that to derive maximum benefits from the applied nutrients, it is highly important to apply the fertilizer at optimum time and required dose. Therefore, optimum dosage of nutrients, particularly nitrogen, and their early application would be advantageous since nitrogen requirement of sugarcane is the greatest during the tillering and the early grand growth phase.

Table 5: Effects of blended fertilizer combination rate and time of application on stalk girth/diameter and node length of sugarcane ratoon crop at Arjo-Didessa

\begin{tabular}{|c|c|c|c|c|c|}
\hline \multirow{3}{*}{ T.No } & \multirow{3}{*}{ Treatment } & \multirow{2}{*}{\multicolumn{2}{|c|}{$\begin{array}{l}\text { Stalk Girth (cm) } \\
\text { Time of Application }\end{array}$}} & \multirow{2}{*}{\multicolumn{2}{|c|}{$\begin{array}{l}\text { Node Length }(\mathrm{cm}) \\
\text { Time of Application }\end{array}$}} \\
\hline & & & & & \\
\hline & & One Month & Two Month & One Month & Two Month \\
\hline 1 & Okg ha ${ }^{-1}$ & 1.88 & 2.37 & 5.5 & 5.63 \\
\hline 2 & $150 \mathrm{~kg} \mathrm{ha}^{-1} \mathrm{BLF}+111 \mathrm{~kg} \mathrm{~N} \mathrm{ha}^{-1}$ & 2.65 & 2.90 & 6.37 & 6.64 \\
\hline 3 & $200 \mathrm{~kg} \mathrm{ha}^{-1} \mathrm{BLF}+103 \mathrm{~kg} \mathrm{~N} \mathrm{ha}^{-1}$ & 2.94 & 2.86 & 6.59 & 6.75 \\
\hline 4 & $250 \mathrm{~kg} \mathrm{ha}^{-1} \mathrm{BLF}+94 \mathrm{~kg} \mathrm{~N} \mathrm{ha}^{-1}$ & 3.11 & 2.78 & 6.83 & 6.92 \\
\hline 5 & $300 \mathrm{~kg} \mathrm{ha}^{-1} \mathrm{BLF}+85 \mathrm{~kg} \mathrm{~N} \mathrm{ha}^{-1}$ & 2.89 & 2.94 & 6.24 & 6.49 \\
\hline 6 & $350 \mathrm{~kg} \mathrm{ha}^{-1} \mathrm{BLF}+76.4 \mathrm{~kg} \mathrm{~N} \mathrm{ha}^{-1}$ & 2.77 & 3.05 & 6.89 & 6.23 \\
\hline 7 & $400 \mathrm{~kg} \mathrm{ha}^{-1} \mathrm{BLF}+68 \mathrm{~kg} \mathrm{~N} \mathrm{ha}^{-1}$ & 2.48 & 2.75 & 6.00 & 7.27 \\
\hline \multirow[t]{4}{*}{8} & $200 \mathrm{~kg} \mathrm{ha}^{-1}$ UREA $+250 \mathrm{~kg} \mathrm{ha}^{-1}$ DAP & 2.60 & 2.60 & 6.15 & 7.40 \\
\hline & Mean & \multicolumn{2}{|c|}{2.72} & \multicolumn{2}{|c|}{6.49} \\
\hline & Cv & \multicolumn{2}{|c|}{4.05} & \multicolumn{2}{|c|}{6.43} \\
\hline & LSD & \multicolumn{2}{|c|}{0.13} & \multicolumn{2}{|c|}{0.49} \\
\hline
\end{tabular}

\section{Effect of Treatments on Number of Node}

Number of nodes was significantly $(P \leq 0.05)$ affected by rates of blended fertilizer but not time of application and interaction of the treatments (Table 3). Relatively high number of nodes (19.33) numbers of internodes per stalk was recorded with treatment combination from $300 \mathrm{~kg} \mathrm{ha}^{-1}$ BLF with $85 \mathrm{~kg} \mathrm{~N} \mathrm{ha}^{-1}$ at one month after harvest (Table 6). The value recorded from $150 \mathrm{~kg} \mathrm{ha}^{-1} \mathrm{BLF}$ with $111 \mathrm{~kg} \mathrm{~N}$ $\mathrm{ha}^{-1}$ and $200 \mathrm{~kg} \mathrm{ha}^{-1}$ BLF with $103 \mathrm{~kg} \mathrm{~N}^{-1}$ of fertilizer rate at one month after harvest and $250 \mathrm{~kg} \mathrm{ha}^{-1}$ BLF with $94 \mathrm{~kg}$ 
$\mathrm{N}$ ha ${ }^{-1}$ and $300 \mathrm{~kg} \mathrm{ha}^{-1}$ BLF with $85 \mathrm{~kg} \mathrm{~N}^{-1}$ of fertilizer rate at one month after harvest were not significantly different, however, at $200 \mathrm{~kg} \mathrm{ha}^{-1}$ UREA with $250 \mathrm{~kg} \mathrm{ha}^{-1}$ DAP at two month (estate norm) of fertilizer rate relatively lower number of internodes were recorded (Table 6).

Node number ranged from 14.33 to 19.33 (Table 6). Numerically, the treatment BLF plus nitrogen application of $200 \mathrm{~kg} \mathrm{ha}^{-1}$ UREA $+250 \mathrm{~kg} \mathrm{ha}^{-1}$ DAP treatment at two month resulted in the lowest node number, whereas the node number was highest in the one month application of $300 \mathrm{~kg} \mathrm{ha}^{-1}$ BLF with $85 \mathrm{~kg} \mathrm{~N} \mathrm{ha}^{-1}$. The node can contribute greatly at times toward total cane yield and affects on total sugar yield were maximum in this study. The node number of cane stalk directly affects plant heights and cane yield harvested from a hectare of lands and sugar yield. Fertilizers do have paramount importance for cane node numbers, length and girth. From this result it was observed that increasing blended fertilizer rate up to same extent increases the number of nodes which have an advantage to get longer stalk which will resulted in high cane yield. This result obtained was in line with Agarwal et al. (2003) who reported that application of $\mathrm{Zn}$ at $17.5 \mathrm{~kg}$ $\mathrm{ha}^{-1}$ increased the average length, girth, internodes number, weight cane per stalk, number of millable canes and yield of sugarcane. From this result it was observed that blended fertilizer increases the number of internodes which have an advantage to get longer stalk which will resulted in high cane yield, biomass yield and sugar recovery.

Table 6: Effects of Blended fertilizer combination rate and time of application on cane yield, plant height and node number of sugarcane ratoon crop at Arjo-Dedessa in 2015.

\begin{tabular}{|c|c|c|c|}
\hline Treatment & Cane Yield t/ha & Plant Height (cm) & Node Number \\
\hline \multicolumn{4}{|l|}{ One month Time of Application } \\
\hline Okg ha ${ }^{-1}$ & 135 & 102.8 & 15 \\
\hline $150 \mathrm{~kg} \mathrm{ha}^{-1} \mathrm{BLF}+111 \mathrm{~kg} \mathrm{~N} \mathrm{ha}^{-1}$ & 150 & 114.2 & 19 \\
\hline $200 \mathrm{~kg} \mathrm{ha}^{-1} \mathrm{BLF}+103 \mathrm{~kg} \mathrm{~N} \mathrm{ha}^{-1}$ & 136 & 133.9 & 19 \\
\hline $250 \mathrm{~kg} \mathrm{ha}^{-1} \mathrm{BLF}+94 \mathrm{~kg} \mathrm{~N} \mathrm{ha}^{-1}$ & 178 & 134.8 & 18.66 \\
\hline $300 \mathrm{~kg} \mathrm{ha}^{-1} \mathrm{BLF}+85 \mathrm{~kg} \mathrm{~N} \mathrm{ha}^{-1}$ & 143 & 136.8 & 19.33 \\
\hline $350 \mathrm{~kg} \mathrm{ha}^{-1} \mathrm{BLF}+76.4 \mathrm{~kg} \mathrm{~N}^{-1}$ & 149 & 128.9 & 17 \\
\hline $400 \mathrm{~kg} \mathrm{ha}^{-1} \mathrm{BLF}+68 \mathrm{~kg} \mathrm{~N} \mathrm{ha}^{-1}$ & 150 & 128.3 & 18.33 \\
\hline $200 \mathrm{~kg} \mathrm{ha}^{-1}$ UREA $+250 \mathrm{~kg} \mathrm{ha}^{-1}$ DAP & 154 & 109.40 & 16.66 \\
\hline Mean & 149.37 & 12.36 & 17.75 \\
\hline LSD (5\%) & 84 & 0.04 & 1.45 \\
\hline \multicolumn{4}{|l|}{ Two Month Time of Application } \\
\hline Okg ha-1 & 135 & 111.30 & 14.66 \\
\hline $150 \mathrm{~kg} \mathrm{ha}^{-1} \mathrm{BLF}+111 \mathrm{~kg} \mathrm{~N}^{-1}$ & 149 & 119.00 & 18 \\
\hline $200 \mathrm{~kg} \mathrm{ha}^{-1} \mathrm{BLF}+103 \mathrm{~kg} \mathrm{~N} \mathrm{ha}^{-1}$ & 137 & 128.5 & 17 \\
\hline $250 \mathrm{~kg} \mathrm{ha}^{-1} \mathrm{BLF}+94 \mathrm{~kg} \mathrm{~N} \mathrm{ha}^{-1}$ & 170 & 127.2 & 17 \\
\hline $300 \mathrm{~kg} \mathrm{ha}^{-1} \mathrm{BLF}+85 \mathrm{~kg} \mathrm{~N}^{-1}$ & 143 & 130.40 & 17 \\
\hline $350 \mathrm{~kg} \mathrm{ha}^{-1} \mathrm{BLF}+76.4 \mathrm{~kg} \mathrm{~N}^{-1}$ & 141 & 128.6 & 18 \\
\hline $400 \mathrm{~kg} \mathrm{ha}^{-1} \mathrm{BLF}+68 \mathrm{~kg} \mathrm{~N} \mathrm{ha}^{-1}$ & 152 & 114.70 & 15.33 \\
\hline $200 \mathrm{~kg} \mathrm{ha}^{-1}$ UREA $+250 \mathrm{~kg} \mathrm{ha}^{-1}$ DAP & 158 & 104.00 & 14.33 \\
\hline Mean & 148.12 & 0.48 & 16.42 \\
\hline LSD (5\%) & 42 & 0.02 & 1.45 \\
\hline CV (\%) & 7.44 & 5.85 & 7 \\
\hline
\end{tabular}

\section{Effect of Treatments on Plant Height}

The different rate of blended fertilizer application resulted with highly significant effect $(P<0.01)$, but time of application and their interaction effect on ratoon cane did not significantly $(P \leq 0.05)$ affect the plant stalk height (Table 3). However, in absolute terms, Plant height was the lowest (102.8) and (104.9) when the ratoon fertilized at the rate of $0 \mathrm{~kg} \mathrm{ha}^{-1}$ (control) and $400 \mathrm{~kg} \mathrm{ha}^{-1} \mathrm{BLF}+68 \mathrm{~kg}$ $\mathrm{N}$ ha $^{-1}$ at one month/estate norm/ consequently while it was the highest when the ratoon fertilized at rate of $250 \mathrm{~kg}$ $\mathrm{ha}^{-1}$ BLF plus $94 \mathrm{~kg} \mathrm{~N}^{-1}$ combination at one month (Table 6). Stalk node number and length contributed for cane height differences for these yield attributes were statistically significant.

Plant height is a main parameter of growth and yield. Although an internodes property (length, thickness and shape) is varietal characters, yet the rate of elongation and length of the internodes and hence plant heights provide information about the general condition of the crop. In (Table 6) application of BLF affect significantly plant height in any particular trend. The analysis of variance also showed that the effect of applied BLF on stalk height was highly significant for all BLF rates.

Gilbert et al. (2006) also illustrates that, the growth of cane plant (increase in size/height or dry weight) is governed by a complex of internal and external factors. The more important external factors affecting growth are soil moisture, temperature, light, soil condition and its nutrient content, of which temperature plays an important role in limiting stalk elongation and girth of sugarcane and the internal factors affecting early establishment and growth of cane are set moisture and nutrient content mainly nitrogen.

Analysis of variance showed that plant height was highly affected by the rate of blended fertilizers (Table 3 ). The maximum difference between the plant heights obtained under different blended fertilizer treatments was about $34 \mathrm{~cm}$, but the presence of constant $\mathrm{N}$ might have promoted the height uniformly and the presence of other nutrients in the blended fertilizers could have brought a change to a significant level (Table 6). 
Dereje Legesse et al.,

This result unlikely with Riffat et al. (2007) who reported that $\mathrm{Zn}$ application between 0 and $10 \mathrm{~kg} / \mathrm{ha}$ level showed statistically no significant difference on plant height of wheat crop. Similarly Debnath et al. (2011), application of $B$ at the rate of 0.75 to $3.0 \mathrm{~kg} / \mathrm{ha}$ found no significant difference on plant height of wheat. However; Sate (2012) reported that plant height of tef significantly affected by application of P2O5 and N with blended fertilizer.

\section{Effect of Treatments on Cane Yield}

The analysis of variance showed that cane yield of ratoon crop were highly influenced $(P<0.01)$ by the main effect of blended fertilizer rate, but timing of application and the interaction of blended fertilizer rate and time of application showed non- significant $(P<0.05)$ effect on the cane yield of the crop (Table 3 ). Higher cane yield had significantly recorded at the rate of $250 \mathrm{~kg} \mathrm{ha}^{-1}$ BLF plus $94 \mathrm{~kg} \mathrm{~N} \mathrm{ha}^{-1}$ at one month (178 t/ha), but statistically it is equivalent result recorded from $250 \mathrm{~kg} \mathrm{ha}^{-1}$ BLF plus $76.4 \mathrm{~kg} \mathrm{~N} \mathrm{ha}^{-1}$ at 2 month $\left(170 \mathrm{t} \mathrm{ha}^{-1}\right)$, the least result was seen on check treatment plot (Table 5). The large number of plant population and weight per stalk formed per hectare resulted significant difference on cane yield (Table 6).

The stalk girth and height were affected significantly by fertilizer rate but not by time of application that it had brought a significant difference on cane yield. In line with this observation, Shrivastava (2006) stated that cane yield is a result of approximately $70 \%$ of cane population, $27 \%$ of cane length and 3\% of cane girth. Jiang (2004) also stated that sugarcane yield per unit land is composed of the cane population and the cane weight. Ashraf et al. (2008) observed that the cane length and diameter, number of tillers per plant, cane yield and sugar recovery increased with the application of nitrogen in the sugarcane varieties. Singh et al. (2002) reported that application of nitrogen in plant and subsequent ratoon crop significantly increased cane yield over control. Nitrogen fertilizer varied significantly for the effects on the yield.

Chowdhury et al. (1986) reported significant yield increase with the application of nitrogen. Yields of cane and sugar were increased when $130 \mathrm{~kg} \mathrm{P}_{2} \mathrm{O}_{5} \mathrm{ha}^{-1}$ was added with $120 \mathrm{~kg} \mathrm{~N} \mathrm{ha}^{-1}$. The results further showed that nitrogen had a prominent effect on yield of sugarcane yield. Chowdhury et al. (1986) confirmed the effect of nitrogen, phosphorus, potassium, sulphur and zinc on the yield of sugarcane. Significant yield increase was recorded with the rates of $\mathrm{N}$ application. Yield of cane and sugar was increased when $130 \mathrm{~kg} \mathrm{P}_{2} \mathrm{O}_{5}$ ha $^{-1}$ was added with $120 \mathrm{~kg} \mathrm{~N}^{-1}$. Saha et al. (1994) reported that the crop responded significantly to $S$ application and increase in cane yield in $\mathrm{S}$ treated plots over control ranged from $7.9-12.5 \%$, which was more applicable up to $40 \mathrm{~kg} \mathrm{~S} \mathrm{ha}^{-1}$. They further calculated the economic dose from $25.0 \mathrm{~kg} \mathrm{~S}$ $\mathrm{ha}^{-1}$ and recorded a net return of Tk. 17.40 per taka investment on sulphur. Dhanasekaran et al. (2004) observed that application of $\mathrm{Zn}$ or Fe or both significantly improved crop yield. The highest cane yield of $157.2 \mathrm{t}$ ha ${ }^{1}$, which was $41.62 \%$ higher than the yield in the control, was obtained in the treatment $\mathrm{Zn}$ at $5 \mathrm{~kg} \mathrm{ha}^{-1}+\mathrm{Fe}$ at 10 $\mathrm{kg} \mathrm{ha}^{-1}$. Agarwal et al. (2003) reported that application of $\mathrm{Zn}$ at $17.5 \mathrm{~kg} \mathrm{ha}^{-1}$ increased the average length, girth, internodes number, weight per cane, number of millable canes and yield of sugarcane.
Sci. Technol. Arts Res. J., Jan-March 2016, 5(1): 1-8

Similar result also reported by Bereket et al. (2014) who found significant increase in straw yield of tef with the application of $8.0 \mathrm{~kg} \mathrm{Zn/ha.} \mathrm{Fageria} \mathrm{et} \mathrm{al.} \mathrm{(2011)} \mathrm{also}$ indicated that application of $\mathrm{S}$ enhanced the photosynthetic assimilation of $\mathrm{N}$ in crop plant. Hence application of $\mathrm{N}$ and $\mathrm{S}$ increased the net photosynthetic rate which in turn increased the dry matter and grain yield as $90 \%$ of dry weight considered to be derived from products formed during photosynthesis (Barker et al 2007). Asefa et al. (2003) also reported that increasing the level of $\mathrm{K}$ from 0 to $100 \mathrm{~kg} / \mathrm{ha}$ resulted in increased aboveground dry biomass.

\section{CONCLUSIONS}

Soil nutrient depletion from time to time in intensive sugarcane production resulted, less fertile and fail to produce higher yield. Hence, nutrient replenishment through the addition of balanced fertilizer in the soil is indispensable for achieving sustainable cane production. The use of chemical fertilizers as a supplemental source of nutrients has been increasing steadily in Ethiopia, but they are not applied in balanced proportions with that soil specific deficiency by most of our farmers and even on large commercial farm Estates. Information, on the effects of blended fertilizer rate and time of application on yield and quality of sugarcane ratoon crop are not known. Therefore, field experiments were conducted with the objectives of assessing effect of blended fertilizer at different rate and time of application on Ratoon sugarcane on yield and quality of cane at Arjo-Didessa Sugar Estate, Western Ethiopia.

The result of the study had a marked effect and showed a highly significant difference for stalk weight, stalk diameter, node length, plant height, stalk population, and cane yield for the different blended fertilizer rate.

Application of blended fertilizer along with adjusted uniformly at $137 \mathrm{~kg} / \mathrm{ha}$ through UREA fertilizer remarkably increased yield of sugarcane. From the seven agronomic parameters measured in the experiment four of them showed highest record result at treatment $250 \mathrm{~kg} \mathrm{ha}^{-1} \mathrm{BLF}$ $+94 \mathrm{~kg} \mathrm{ha}^{-1}$ cane yield of maximum $178 \mathrm{th}^{-1}$ due to use of blended fertilizer adjusting with nitrogen could increase $28 \mathrm{t} \mathrm{ha}^{-1}$ of cane yield than the average cane yield field performance standard settled by Arjo-Didessa Sugar Factory estates $150 \mathrm{t} \mathrm{ha}^{-1}$.

Based on the results of this study, it is generally concluded that, early (one month after harvest) application of blended fertilizer mixed with nitrogen $\left(250 \mathrm{~kg} \mathrm{ha}^{-1}\right.$ BLF \& $94 \mathrm{~kg} \mathrm{~N} \mathrm{ha}^{-1}$ ) improved the ratoon cane crucial yield determining parameters through resulting in higher weight per stalk, stalk girth, cane yield, sugar yield and node length, . However, these treatments had apparently no significant effect on others growth parameters performance (plant height and node length) and in quality parameters of ratoon commercial crop as compared to the treatment application of $\mathrm{N} 250 \mathrm{~kg} \mathrm{ha}^{-1}$ BLF with $94 \mathrm{~kg} \mathrm{~N}^{-}$ 1 for ratoon commercial crop. Therefore, treating the ratoon cane by $250 \mathrm{~kg} \mathrm{ha}^{-1} \mathrm{BLF}$ with $94 \mathrm{~kg} \mathrm{~N}^{-1}$ at one month after harvest had evidently the advantage of improving ratoon cane quality and growth performance. However, it is premature to give a conclusive recommendation since the experiment was conducted only for one season with one variety. Hence, similar studies should be conducted by including more blended fertilizer with nitrogen with different rate and times of 
Dereje Legesse et al.,

application on ratoon cane for this and other varieties under production in the Estate, to come up with a conclusive recommendation.

\section{Conflict of Interest}

None declared

\section{REFERENCES}

Agarwal, M.L., Sheshodia, O.P.S. and Laxman, S. (2003). Effect of trace elements nutrition on growth, yield and juice quality of sugarcane. Bhartiya Krishi Anusandhan Patrika 18(3/4): 147-152.

Ashraf, M.Y., Hussain, F., Akhter, J., Gul, A., Ross, M. and Ebert, G. (2008). Effects of different sources of nitrogen and supra optimal level of potassium fertilization on growth, yield and nutrient uptake by sugarcane grown under saline conditions. Pakistan Journal of Botany 40(4):1521-1531.

Assefa, K., Merker, A. and Tefera, H. (2003). Multivariate analysis of diversity of tef (Eragrostis tef (Zucc.) Trotter) germplasm from western and southern Ethiopia. Hereditas 138: 228-236. Lund, Sweden.

Barker A.V. and David J.P. (2007). Hand book of plant nutrition: Books in soil, plant and environment,177, Taylor and francis press, Boca rato, Lonndon, New york.

Bereket H., Dawit H., Mehretab H., Gebremedhin G.(2014). Effects of Mineral Nitrogen and Phosphorus Fertilizers on Yield and Nutrient Utilization of Bread Wheat (Tritcum aestivum) on the Sandy Soils of Hawzen District, Northern Ethiopia. Agriculture, Forestry and Fisheries 3(3): 189-198.

Bekabil Fufa., Befekadu Behute., Rupert Simons and Tareke Berhe (2011). Strengthening the tef Value Chain in Ethiopia (Unpublished Report). pp.12. Agricultural Transformation Agency.

Bokhtiar, S.M. and Sakurai, K. (2005). Effect of application of inorganic and organic fertilizers on growth, yield and quality of sugarcane. Sugar Tech 7(1): 33-37.

Brady, N.C. and Well, R.R. (2000). The nature and properties of soil. $13^{\text {th }}$ ed. Person

CSA (2011). Agricultural Sample Survey Report on area and production of major crops, 1, Addis Ababa.

Chowdhury, M.K.A. and Rahman, M.H. (1986). Effect of NPKSZn fertilization on sugarcane in calcareous soils. Bangladesh Journal of Sugarcane 8: 31-35.

Debnath, M. R., Jahiruddin M., Rahman, M.M. and Haque, M. A. (2011). Determining optimum rate of boron application for higher yield of wheat in Old Brahmaputra Floodplain soil. Journal of Bangladesh Agriculture University 9(2): 205-210.

Dhanasekaran, K. and Bhuvaneswari, R. (2004). Effect of zinc and iron humates application on the yield and quality of sugarcane. Indian Sugar 53(11): 907-912.

ESISCSh.Co (Ethiopian Sugar Industry support centre Share Company), 2004. Investment opportunities in Ethiopia's sugar industry. Addis Ababa, Ethiopia. Unpublished.

Facounnier, R. (1993). Sugarcane. The Tropical Agriculturalist. The MacMillan Press Ltd.

Fageria N.K., Baligar U.C. and Jones C.A . (2011). Mineral nutrition field crop; 3rd ed, Taylor and Francis press, Boca Raton.

Fauconnier, R. (1993). Sugar cane. The Tropical Agriculturalist. The Macmillan Press Ltd.,London.
Sci. Technol. Arts Res. J., Jan-March 2016, 5(1): 1-8

Hunsingi, G. (1993). Production of sugarcane, theory and practice. Advanced Series in Agricultural Sciences. India.

Jiang, Y. (2004). Modern Sugarcane Cultivation Technology. Sugarcane Industry Research Institute. Guangzhou, China.

Kumar, V. and Verma, S.K. (2002). Influence of use of organic manure in combination with inorganic fertilizers on sugarcane and soil fertility. Indian Sugar 52(3): 177181.

Legendre, B.L. (2001). Sugarcane production handbook. Pub. 2859. Louisiana State University Agriculture Center, Baton Rouge, LA.

Nadeem, M.A., Sarwar, M.A., Ghaffar, A., Ahmad, F. and Hussain, F. (2011). Studies on the performance of some sugarcane genotypes at Faisalabad. Sugarcane Research Institute, AARI, Pakistan.

Nosheen, N.E. and Ashraf, M.(2003). Statistical Analysis of Certain Traits that Influence Sugar Recovery of Selected Sugarcane Varieties. Pakistan Journal of Biological Sciences 6: 99-104.

Orgeron, A.J. ( 2003). Planting Rate Effects on Sugarcane Yield Trials. MSc. Thesis, Louisiana State University and Agricultural College. USA.

Paul, G.C., Rahman, M.M. and Rahman, A.M. (2005). Integrated nutrient management with organic and inorganic fertilizers on productivity of sugarcane ratoon in Bangladesh. Sugar Tech 7(2/3): 20-23.

Raskar, B.S. and Bhoi, P.G. (2003). Yield attributed of sugarcane as influenced by intra-row spacing, fertilizer levels and planting materials. Indian Sugar 5:305.

Rehm, G.M. Schmitt and Munter, R. (1993). Fertilizing wheat in Minnesota. Minnesota extension service AG-FO-3772B. University of Minnesota. 21p.

Riffat, S., Samin M.K., Mahmud. R. (2007). Effect of Zinc and zinc uptake by wheat on some soils of Bangladish. Journal of soil. Naturw 1: 07-14.

Ryan, J.( 2008). A Perspective on balanced fertilization in the Mediterranean Region. Turky Journal of Agriculture 32: 79-89.

Saha, S.C., Uddin, M.M. and Ghosh, S.R. (1994). Effect of rate and time of sulphur application on sugarcane. Bangladesh Journal of Sugarcane 18-20: 30-36.

Sarwar, M.A., Husain, F., Ghaffar, A. and Nadeem, M.A. (2011). Effect of some newly introduced fertilizers in sugarcane. Shakarganj Sugar Research Institute, Ayub Agricultural Research Institute, Faisalabad, Pakistan.

Shankaraiah, C. (2007). Nitrogen management through biological process on nitrogen use efficiency in sugarcane and environmental protection. Sugar Tech 9(2\&3): 132136.

Singh, T. and Singh, P.N. (2002). Effect of integrated nutrient management on soil fertility status and productivity of sugarcane grown under sugarcane based cropping sequence. Indian Journal of Sugarcane Technology 17(1\&2): 53-55.

Sonia, O., Ra fael Quintero, D., Jesus E. Larrahondo and Alonso, J. (2007). Evaluation of two analytical methods for quantifying nitrogen losses by volatilization in soils of the Cauca River Valley. Sugar Tech 9(2\&3): 128-131.

Sundara, B. (2000). Sugarcane cultivation. Vicas Publishing House Pvt Ltd. New Delhi.

Shrivastava, A.K. ( 2006). Sugarcane at glance. International Book Distributing Co. (IBDC).Lucknow, U.P. India. 